\title{
HUBUNGAN ANTARA PENGELOLAAN SEKOLAH, IKLIM SEKOLAH, DAN PARTISIPASI MASYARAKAT DALAM MENINGKATKAN MUTU SEKOLAH DENGAN EFEKTIVITAS SEKOLAH DI PROVINSI JAWA TIMUR
}

\begin{abstract}
Sediono Abdullah*
Abstract: The objective of this research is to get information on the relationships among school management, school climate, and community participation in improving educational quality toward school effectiveness at schools which received Piloting School Based Management Program.The research was conducted at the schools in Probolinggo district, East Java Province with $n=100$, selected randomly. The research concludes that there is positive correlation between: (1) school management and school effectiveness; (2) school climate and school effectiveness; (3) community participation in improving educational quality and school effectiveness. Furthermore, there is positive correlation between those three independent variables with school effectiveness. Therefore school effectiveness could be improved by enhancing school management, school climate and community participation in improving educational quality.
\end{abstract}

Keywords: School management, school climate, community participation, and school effectiveness.

\section{PENDAHULUAN}

Penyelenggaraan sekolah yang efektif merupakan tanggungjawab bersama antara Pemerintah, Pemerintah Daerah, dan Masyarakat sebagai amanat desentralisasi pendidikan. Tujuan penyelenggaraan desentralisasi pendidikan tersebut adalah agar Pemerintah Daerah mampu meningkatkan azas demokrasi, peran serta masyarakat, pemerataan dan keadilan serta memperhatikan potensi dan keanekaragaman daerah. Dengan kebijakan ini, memunculkan bentuk pengelolaan sekolah yang berbasis pada keunggulan lokal dan kekhususan karakteristik sekolah yang disebut dengan manajemen berbasis sekolah (School Based Management) dan pendidikan yang berbasis masyarakat (Community Based Education). Penerapan Manajemen Berbasis Sekolah (MBS) serta perintisan sekolah yang berbasis masyarakat serta sekolah yang berbasis keunggulan lokal menuntut perubahan dalam kepemimpinan kepala sekolah dalam mengelola sumberdaya pendidikan di daerah masing-masing. Kepala sekolah harus mampu meningkatkan mutu pendidikan melalui berbagai pendekatan yang berbasis kepada masyarakat (Community Based Education) dan kebutuhan sekolah (School Based Management).

Perubahan sistem sentralisasi ke desentralisasi memberikan lebih banyak wewenang kepada kepala sekolah dan masyarakat untuk mengembangkan pendidikan yang lebih sesuai dengan kebutuhan masing-masing daerah dalam mengelola sumber dayanya sendiri. Kenyataan menunjukkan bahwa perjalanan menuju sukses MBS ini tidaklah mudah, ada sekolah yang berhasil menerapkan sistem ini, namun masih ada sebagian juga yang belum berhasil. Ciri sekolah yang berhasil menerapkan MBS adalah sekolah yang memiliki kepala sekolah, guru, dan masyarakat yang dapat bekerjasama secara aktif untuk mengembangkan sekolahnya melalui tiga pilar: pengelolaan sekolah secara mandiri, Pembelajaran yang Aktif, Kreatif, Efektif, dan Menyenangkan (PAKEM), dan peranserta masyarakat dalam meningkatkan mutu

\footnotetext{
* Penanggungjawab Kerjasama Direktorat Pembinaan Pendidikan dan Pelatihan
} 
sekolah. Di sinilah peran kepala sekolah dituntut adanya seni memimpin suatu sekolah sehingga terjadi kesamaan visi, misi, dan rencana pengembangan sekolah serta program-program yang sinergis antara warga sekolah (kepala sekolah, guru, tenaga tata usaha dan siswa), dengan orang tua siswa serta masyarakat.

Dari latar belakang masalah di atas, dapat dirumuskan masalahnya sebagai berikut: (1) Apakah terdapat hubungan positif antara pengelolaan sekolah dengan efektivitas sekolah? (2) Apakah terdapat hubungan positif antara iklim sekolah dengan efektivitas sekolah? (3) Apakah terdapat hubungan positif antara partisipasi masyarakat dalam meningkatkan mutu sekolah dengan efektivitas sekolah? (4) Apakah terdapat hubungan positif secara bersama-sama antara pengelolaan sekolah, iklim sekolah, dan partisipasi masyarakat dalam meningkatkan mutu sekolah dengan efektivitas sekolah?

\section{Efektivitas Sekolah}

Efektivitas sekolah merupakan suatu ukuran yang dapat mengukur seberapa jauh sasaran (baik kuantitas, kualitas, maupun waktu) telah tercapai. Makin besar persentase sasaran atau target yang dicapai, makin tinggi tingkat efektivitasnya. Berdasarkan penelitian di beberapa sekolah, Birmingham (1997) menyebutkan terdapat tujuh proses yang mempengaruhi hampir semua aktivitas dalam kehidupan sekolah: (1) Praktek mengajar dan belajar, (2) Latihan kepemimpinan, (3) Praktek manajemen dan organisasi, (4) Praktek dalam review kolektif, (5) Penciptaan lingkungan yang cocok untuk belajar, (6) Promosi dari pengembangan staf, dan (7) Mendorong keterlibatan masyarakat dan orang tua. Paine, et al (1992) menjelaskan sekolah yang efektif pada pendidikan dasar mempunyai ciri sebagai berikut: (1) Kepemimpinan yang bertujuan, (2) Keterlibatan wakil kepala sekolah, (3) Keterlibatan guru, (4) Konsistensi diantara guru, (5) Pelajaran yang terstruktur, (6) Intelektual yang menantang, (7) Lingkungan yang berpusat pada pekerjaan, (8) Fokus terbatas dalam sesi, (9) Komunikasi yang maksimum antara guru dan siswa, (10) Keterlibatan orang tua, (11) Catatan yang teratur, (12) Iklim yang positif. (

Menurut Schmoker (2006) terdapat 8 faktor yang mempengaruhi efektivitas sekolah yang disebut juga sebagai faktor organisasi yaitu: (1) Kurikulum yang terfokus pada kepemimpinan sekolah, (2) Iklim yang mendukung di lingkungan sekolah, (3) Menekankan pada kurikulum dan pembelajaran, (4) Mempunyai tujuan yang jelas dan harapan yang tinggi pada siswa, (5) Mempunyai sistem monitoring terhadap kinerja dan prestasi, (6) Berjalannya pengembangan staf, (7) Keterlibatan orang tua dan (8) Dukungan dari luar. Selanjutnya dijelaskan kunci untuk mengembangkan sekolah secara berkelanjutan adalah sebagai berikut: (1) Bekerja dalam tim, (2) Mencapai tujuan, (3) Pencatatan data, (4) Hasil yang cepat, (5) Penelitian, (6) Mendefinisikan ulang hasil, (7) Kesempatan untuk melaksanakan tindakan diantara daerah subjek.

Dari beberapa konsep di atas, dapat disintesiskan efektivitas sekolah adalah keberhasilan pencapaian sasaran mutu sekolah dengan mendayagunakan sumberdaya pendidikan untuk pelaksanaan proses pendidikan, program sekolah dan pencapaian hasil serta tujuan pendidikan di sekolah.

\section{Pengelolaan Sekolah}

Menurut Schmoker bahwa proses pengelolaan sekolah meliputi: (1) Perencanaan dan analisis lingkungan sekolah, (2) Perumusan strategi, (3) Implementasi strategi, (4) Evaluasi dan pengendalian. Proses pengelolaan sekolah merupakan hasil dari interaksi keempat elemen yaitu pengamatan dan analisis lingkungan sekolah untuk menyusun perencanaan dan kebijakan sekolah, perumusan strategi, implementasi strategi dan 
evaluasi serta pengendalian. Kepala Sekolah bersama guru dan masyarakat/komite sekolah mengamati lingkungan eksternal untuk melihat kesempatan dan ancaman dan mengamati lingkungan internal untuk melihat kekuatan dan kelemahan. Faktor-faktor yang paling penting untuk masa depan organisasi sekolah disebut faktor-faktor strategis yang diringkas dengan S.W.O.T., yaitu kekuatan (Strengths), kelemahan (Weaknesses), kesempatan (Opportunities), dan ancaman (Threats). Berdasarkan berbagai konsep dan teori di atas, dapat dirumuskan sintesis pengelolaan sekolah, sebagai berikut: pengelolaan sekolah adalah sekumpulan keputusan dan tindakan yang menghasilkan perumusan (formulasi) dan pelaksanaan (implementasi) kebijakan dan program sekolah secara bersama-sama untuk mencapai sasaran mutu sekolah yang komprehensif.

\section{Iklim Sekolah}

Menurut Newell (1978) dikatakan bahwa iklim organisasi menunjuk pada konsep sistem yang mencerminkan keseluruhan gaya hidup suatu organisasi. Berdasarkan definisi ini iklim suatu organisasi mencakup lingkungan manusia di mana pegawai dalam suatu organisasi melakukan pekerjaan. Owens (1987) menjelaskan lebih lanjut tentang iklim organisasi "is the study of perceptions that individuals have of various aspects of the environment in the organization" berdasarkan defenisi di atas iklim organisasi dinyatakan sebagai persepsi yang dimiliki individu tentang aspek lingkungan dalam suatu organisasi. Menurut Owens iklim sekolah dapat digambarkan sebagai suatu sistem sosial, yang dinyatakan sebagai "the characteristics of the total environments in school building". Suatu sistem sekolah terdiri dari subsistem-subsistem yang saling berinteraksi, dan saling bergantungan satu dengan yang lain untuk mencapai suatu tujuan. Owens lebih lanjut menyatakan empat dimensi yang terkait dengan iklim sekolah sebagai suatu unit organisasi yaitu: (1) ekologi, (2) meliu, (3) sistem sosial dan (4) kebudayaan. Keempat dimensi ini saling berhubungan secara dinamik.

Dari beberapa konsep di atas, dapat disintesiskan bahwa iklim sekolah adalah kondisi dinamis yang mencerminkan karakteristik lingkungan sekolah secara total termasuk penilaian warga sekolah dan hubungan interaksi anggota dalam organisasi sekolah yang terdiri dari dimensi lingkungan fisik dan lingkungan sosial organisasi.

\section{Partisipasi Masyarakat dalam meningkatkan Mutu Sekolah}

Sekolah dalam rintisan program MBS diharapkan dapat berhubungan dengan keluarga dan masyarakat untuk mendukung perkembangan dan pencapaian keberhasilan belajar siswa. Peran masyarakat dalam rintisan manajemen berbasis sekolah diharapkan masyarakat dapat membantu meningkatkan mutu sekolah dengan tetap menyekolahkan anaknya, membiayai keperluan sekolah anaknya, serta bantuan lain yang diperlukan. Peran serta masyarakat ini pun diatur dalam Peraturan Pemerintah N0. 39

tahun 1992. Pada pasal 3 berbunyi peran serta masyarakat adalah berbagai kegiatan masyarakat dalam pendidikan nasional. Adapun jenis partisipasi masyarakat menurut Soediono, et al dapat diuraikan dalam tujuh komponen yaitu: (1) Menggunakan jasa pelayanan yang tersedia; (2) Peran serta dengan memberikan kontribusi dana, bahan dan tenaga; (3) Peran serta dalam bentuk keikutsertaan, yang berarti menerima secara pasif apa yang telah diputuskan oleh pihak lain; (4) Peran serta melalui konsultasi mengenai hal-hal tertentu; (5) Keterlibatan dalam memberikan pelayanan tertentu; (6) 
Keterlibatan dalam pelaksana kegiatan yang telah didelegasikan; (7) Peran serta yang sebenarnya dalam pengambilan keputusan pada berbagai jenjang.

Berdasarkan berbagai konsep dan teori di atas, dapat dirumuskan sintesis partisipasi masyarakat sebagai berikut: Partisipasi masyarakat adalah kepedulian masyarakat yang diwujudkan dalam bentuk kemitraan, penyediaan tenaga, uang dan alat serta bahan, konsultasi dan pelayanan masyarakat dalam meningkatkan mutu sekolah.

\section{METODE}

Metode yang digunakan dalam penelitian ini adalah survei dengan pendekatan korelasional. Penelitian ini dilaksanakan pada semua sekolah yang mendapat treatmen rintisan program manajemen berbasis sekolah di Kabupaten Probolinggo, Provinsi Jawa Timur mulai bulan Agustus sampai Desember 2008. Adapun sampel sebanyak 100 kepala sekolah yang dipilih secara acak.

\section{HASIL DAN PEMBAHASAN} berikut :

Hasil uji normalitas dan homogenitas data disajikan pada tabel 1 dan 2 sebagai

Tabel 1

Hasil Pengujian Normalitas

\begin{tabular}{|c|c|c|c|c|}
\hline No & Galat Taksiran Regresi & L-hitung & L-tabel & Kesimpulan \\
\hline 1 & $\mathrm{X}_{1}$ & $0,0697 \mathrm{~ns}$ & 0,0886 & Normal \\
\hline 2 & $\mathrm{X}_{2}$ & $0,0764 \mathrm{~ns}$ & 0,0886 & Normal \\
\hline 3 & $\mathrm{X}_{3}$ & $0,0880 \mathrm{~ns}$ & 0,0886 & Normal \\
\hline
\end{tabular}

Keterangan: ns : not signifikan

n : $100, a=0,05$.

Hasil pengujian normalitas di atas menunjukkan bahwa $\mathrm{L}_{\text {hit }}<\mathrm{L}_{\text {tab. }}$. Hal tersebut berarti bahwa pada $\alpha=0,05$ data penelitian berasal dari populasi yang berdistribusi normal.

\section{Uji Homogenitas}

Uji homogenitas data dilakukan dengan menggunakan uji Barlett. Pengujian dengan teknik ini dilakukan dengan cara membandingkan harga $\chi^{2}$ hit dengan harga $\chi^{2}$ tab. Jika harga $\chi^{2}$ hit $<\chi^{2}$ tab, maka varians kedua variabel adalah homogen, dan sebaliknya bila

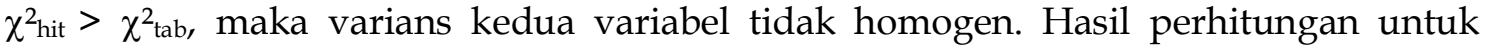
pengujian homogenitas varians skor $\mathrm{Y}$ ditinjau dari skor variabel bebas tertera pada tabel 2 .

Tabel 2

Hasil Pengujian Homogenitas Varians Kelompok skor $Y$ ditinjau dari Skor $X_{i}$

\begin{tabular}{|c|c|c|c|c|}
\hline No & $\begin{array}{c}\text { Varians Kelompok Skor } \\
\text { Y ditinjau dari Xi }\end{array}$ & $\chi^{2}$ hit & $\chi^{2}$ tab & Kesimpulan \\
\hline 1 & Y atas $\mathrm{X}_{1}$ & 36,85 & 40,1 & Homogen \\
\hline
\end{tabular}




\begin{tabular}{|c|c|c|c|c|}
\hline 2 & $\mathrm{Y}$ atas $\mathrm{X}_{2}$ & 21,82 & 35,17 & Homogen \\
\hline 3 & $\mathrm{Y}$ atas $\mathrm{X}_{3}$ & 24,06 & 37,65 & Homogen \\
\hline
\end{tabular}

Keterangan $: \mathrm{n}=100, \alpha=0,05$

Berdasarkan tabel di atas dapat disimpulkan bahwa pada $\alpha=0,05$, varians kelompok skor variabel terikat terhadap skor variabel bebas bersifat homogen.

\section{Pengujian Hipotesis}

Hipotesis pertama penelitian ini adalah, terdapat hubungan positif antara pengelolaan sekolah dengan efektivitas sekolah. Pengujian hipotesis pertama dilakukan dengan menggunakan rumus korelasi Pearson Product Moment. Berdasarkan hasil perhitungan, diperoleh koefisien korelasi antara pengelolaan sekolah dengan efektivitas sekolah, $\mathrm{r}_{\mathrm{y} 1}$ $=0,76$. Angka ini mengisyaratkan bahwa hubungan antara pengelolaan sekolah dengan efektivitas sekolah adalah positif. Uji keberartian koefisien korelasi antara pengelolaan sekolah dengan efektivitas sekolah dilakukan dengan menggunakan uji-t. Hasil perhitungan pengujian keberartian koefisien korelasi tersebut tertera pada tabel 3 .

Tabel 3

Hasil Pengujian Keberartian Korelasi antara $X_{1}$ dengan $Y$

\begin{tabular}{|c|c|c|c|c|}
\hline $\mathrm{n}$ & $\mathrm{r}_{\mathrm{y} 1}$ & $\mathrm{t}_{\text {hit }}$ & $\mathrm{t}_{\mathrm{tab}} \mathrm{\alpha}=0,05$ & $\mathrm{t}_{\mathrm{tab}} \mathrm{\alpha}=0,01$ \\
\hline 100 & 0,76 & $11,54^{* *}$ & 1,66 & 2,36 \\
\hline
\end{tabular}

Keterangan :

$\mathrm{r}_{\mathrm{y} 1}=$ koefisien antara $\mathrm{X}_{1}$ dengan $\mathrm{Y}$

$* *=$ koefisien korelasi sangat signifikan $\left(t_{\text {hit }}=11,54>t_{\text {tab }}=2,36\right.$ pada $a=0,01$ )

Berdasarkan pengujian tersebut dapat disimpulkan bahwa terdapat hubungan positif antara pengelolaan sekolah dengan efektivitas sekolah. Dari koefisien korelasi tersebut dapat dihitung pula koefisien determinasinya $\left(\mathrm{r}^{2}{ }_{\mathrm{y} 1}\right)$ yaitu $0,76^{2}=0,58$. Hal ini berarti bahwa $58 \%$ dari efektivitas sekolah dapat dijelaskan oleh pengelolaan sekolah.

Untuk menjelaskan hubungan antara pengelolaan sekolah dengan efektivitas sekolah, jika variabel iklim sekolah dan partisipasi masyarakat dalam meningkatkan mutu sekolah dikontrol, dilakukan analisis koefisien korelasi parsial. Koefisien korelasi parsial yang diperoleh antara $Y$ dengan $X_{1}$, dimana $X_{2}$ dan $X_{3}$ dikontrol $\left(r_{y 1.23}\right)=0,325$. Uji keberartian koefisien korelasi parsial antara $X_{1}$ dengan $Y$, dengan pengontrolan terhadap variabel $X_{2}$ dan $X_{3}$ dilakukan dengan uji-t. Hasil uji keberartian korelasi parsial tertera pada tabel 4.

\section{Tabel 4}

Hasil Pengujian Keberartian Koefisien Korelasi Parsial antara $X_{1}$ dengan $Y$

\begin{tabular}{|c|c|c|c|c|}
\hline Koefisien Korelasi parsial & $\mathrm{r}_{\text {hit }}$ & $\mathrm{t}_{\text {hit }}$ & $\begin{array}{c}\mathrm{t}_{\mathrm{tab}} \\
\mathrm{a}=0,05\end{array}$ & $\begin{array}{c}\mathrm{t}_{\mathrm{tab}} \\
\mathrm{a}=0,01\end{array}$ \\
\hline $\mathrm{r}_{\mathrm{y} 1.2}$ & 0,444 & $4,94^{* *}$ & 1,66 & 2,36 \\
\hline
\end{tabular}




\begin{tabular}{|c|c|c|c|c|}
\hline $\mathrm{r}_{\mathrm{y} 1.3}$ & 0,584 & $7,13^{* *}$ & 1,66 & 2,36 \\
\hline $\mathrm{r}_{\mathrm{y} 1.23}$ & 0,325 & $3,40^{* *}$ & 1,66 & 2,36 \\
\hline
\end{tabular}

Keterangan :

** $=$ koefisien korelasi parsial sangat signifikan $\left(t_{\text {hit }}=3,40>t_{t a b}=2,36\right.$ pada $a=$ $0,01)$

Interpretasi dari hasil analisis ini adalah, jika variabel iklim sekolah $\left(\mathrm{X}_{2}\right)$ dan partisipasi masyarakat dalam meningkatkan mutu sekolah $\left(X_{3}\right)$ dikontrol, ternyata variabel pengelolaan sekolah $\left(\mathrm{X}_{1}\right)$ mempunyai hubungan positif dan berarti dengan efektivitas sekolah (Y).

Hipotesis kedua penelitian ini adalah terdapat hubungan yang positif antara iklim sekolah dengan efektivitas sekolah. Pengujian hipotesis kedua dilakukan dengan menggunakan rumus korelasi Pearson Product Moment. Berdasarkan hasil perhitungan, diperoleh koefisien korelasi antara iklim sekolah dengan efektivitas sekolah, $\mathrm{r}_{\mathrm{y} 2}=0,72$. Uji keberartian koefisien korelasi antara iklim sekolah dengan efektivitas sekolah dilakukan dengan menggunakan uji-t. Hasil perhitungan uji keberartian koefisien korelasi tersebut tertera pada tabel 5 .

Tabel 5

Hasil Perhitungan Keberartian Korelasi antara $X_{2}$ dengan $Y$

\begin{tabular}{|c|c|c|c|c|}
\hline $\mathrm{n}$ & $\mathrm{r}_{\mathrm{y} 2}$ & $\mathrm{t}_{\text {hit }}$ & $\mathrm{t}_{\mathrm{tab}} \mathrm{\alpha}=0,05$ & $\mathrm{t}_{\mathrm{tab}} \mathrm{\alpha}=0,01$ \\
\hline 100 & 0,72 & $10,3^{* *}$ & 1,66 & 2,36 \\
\hline
\end{tabular}

Keterangan :

$\mathrm{r}_{\mathrm{y} 2}$ : koefisien korelasi antara $\mathrm{X}_{2}$ dengan $\mathrm{Y}$

** : koefisien korelasi sangat signifikan $\left(t_{\text {hit }}=10,3>t_{\text {tab }}=2,36\right.$ pada $\left.a=0,01\right)$

Berdasarkan data pada tabel 6, dapat disimpulkan bahwa terdapat hubungan positif dan sangat signifikan antara iklim sekolah dengan efektivitas sekolah. Dari koefisien korelasi tersebut dapat dihitung pula koefisien determinasinya $\left(\mathrm{r}^{2} \mathrm{y} 2\right)$ sebesar $0,72^{2}=0,52$. Hal ini berarti bahwa $52 \%$ dari efektivitas sekolah dapat dijelaskan oleh iklim sekolah. Untuk menjelaskan hubungan antara iklim sekolah dengan efektivitas sekolah, jika

variabel pengelolaan sekolah dikontrol, dilakukan analisis korelasi parsial. Koefisien korelasi parsial yang diperoleh antara $Y$ dengan $X_{2}$, dimana $X_{1}$ dan $X_{3}$ dikontrol $\left(r_{y 2.13}\right)=$ 0,296. Uji keberartian koefisien korelasi parsial antara $X_{2}$ dengan $Y$, dengan pengontrolan terhadap variabel $X_{1}$ dan $X_{3}$ dilakukan dengan uji-t. Hasil uji keberartian korelasi parsial tertera pada tabel 6 .

Tabel 6

Hasil Pengujian Keberartian Koefisien Korelasi Parsial antara $X_{2}$ dengan $Y$

\begin{tabular}{|c|c|c|c|c|}
\hline $\begin{array}{c}\text { Koefisien } \\
\text { Korelasi parsial }\end{array}$ & $t_{\text {hit }}$ & $t_{\text {hit }}$ & $\begin{array}{c}t_{\text {tab }} \\
\mathrm{a}=0,05\end{array}$ & $\begin{array}{c}t_{\text {tab }} \\
\mathrm{a}=0,01\end{array}$ \\
\hline $\mathrm{r}_{\mathrm{y} 2.1}$ & 0,300 & $3,11^{* *}$ & 1,66 & 2,36 \\
\hline $\mathrm{r}_{\mathrm{y} 2.3}$ & 0,572 & $6,91^{* *}$ & 1,66 & 2,36 \\
\hline $\mathrm{r}_{\mathrm{y} 2.13}$ & 0,296 & $3,08^{* *}$ & 1,66 & 2,36 \\
\hline
\end{tabular}

Keterangan :

** : koefisien korelasi parsial sangat signifikan $\left(\mathrm{t}_{\text {hit }}=3,08>\right.$

$$
\left.t_{\text {tab }}=2,36 \text { pada } \quad \alpha=0,01\right)
$$


Interpretasi dari hasil analisis di atas adalah, jika variabel pengelolaan sekolah dan partisipasi masyarakat dikontrol, ternyata variabel iklim sekolah mempunyai hubungan positif dengan efektivitas sekolah.

Hipotesis ketiga penelitian ini adalah terdapat hubungan yang positif antara partisipasi masyarakat dalam meningkatkan mutu sekolah dengan efektivitas sekolah. Pengujian hipotesis ketiga dilakukan dengan menggunakan rumus korelasi Pearson Product Moment. Berdasarkan hasil perhitungan, diperoleh koefisien korelasi antara partisipasi masyarakat dalam meningkatkan mutu sekolah dengan efektivitas sekolah, $\mathrm{r}_{\mathrm{y} 3}=0,63$. Uji keberartian koefisien korelasi antara partisipasi masyarakat dalam meningkatkan mutu sekolah dengan efektivitas sekolah dilakukan dengan menggunakan uji-t. Hasil perhitungan uji keberartian koefisien korelasi tersebut tertera pada tabel 7.

Tabel 7

Hasil Perhitungan Keberartian Korelasi antara $X_{3}$ dengan $Y$

\begin{tabular}{|c|c|c|c|c|}
\hline $\mathrm{n}$ & $\mathrm{r}_{\mathrm{y} 3}$ & $\mathrm{t}_{\text {hit }}$ & $\begin{array}{c}\mathrm{t}_{\mathrm{tab}} \boldsymbol{\alpha}= \\
0,05\end{array}$ & $\mathrm{t}_{\mathrm{tab}} \mathrm{\alpha}=0,01$ \\
\hline 100 & 0,63 & $7,96^{* *}$ & 1,66 & 2,36 \\
\hline
\end{tabular}

Keterangan :

$r_{y 3}$ : koefisien korelasi antara $X_{3}$ dengan $Y$

** : koefisien korelasi sangat signifikan $\left(t_{\text {hit }}=7,96>t_{\text {tab }}=2,36\right.$ pada $\left.a=0,01\right)$

Berdasarkan data pada tabel 7, dapat disimpulkan bahwa terdapat hubungan positif dan sangat signifikan antara partisipasi masyarakat dalam meningkatkan mutu sekolah dengan efektivitas sekolah. Dari koefisien korelasi tersebut dapat dihitung pula koefisien determinasinya $\left(\mathrm{r}_{\mathrm{y} 3}\right)^{2}$ sebesar $0,63^{2}=0,39$. Hal ini berarti bahwa $39 \%$ dari efektivitas sekolah dapat dijelaskan oleh partisipasi masyarakat dalam meningkatkan mutu sekolah.

Untuk menjelaskan hubungan antara partisipasi masyarakat dalam meningkatkan mutu sekolah dengan efektivitas sekolah, jika variabel pengelolaan sekolah dan iklim sekolah dikontrol, dilakukan analisis korelasi parsial. Koefisien korelasi parsial yang diperoleh antara $Y$ dengan $X_{3}$, dimana $X_{1}$ dan $X_{2}$ dikontrol $\left(r_{y 3.12}\right)=0,229$. Uji keberartian koefisien korelasi parsial antara $X_{3}$ dengan $Y$, dengan pengontrolan terhadap variabel $X_{1}$ dan $X_{2}$ dilakukan dengan uji-t. Hasil uji keberartian korelasi parsial tertera pada tabel 8.

Tabel 8

Hasil Pengujian Keberartian Koefisien Korelasi Parsial antara $X_{3}$ dengan $Y$

\begin{tabular}{|c|c|c|c|c|}
\hline $\begin{array}{c}\text { Koefisien } \\
\text { Korelasi } \\
\text { parsial }\end{array}$ & $r_{\text {hit }}$ & $t_{\text {hit }}$ & $\begin{array}{c}t_{\text {tab }} \\
\mathrm{a}=0,05\end{array}$ & $\begin{array}{c}t_{\text {tab }} \\
\mathrm{a}=0,01\end{array}$ \\
\hline $\mathrm{r}_{\mathrm{y} 3.1}$ & 0,235 & $2,39^{* *}$ & 1,66 & 2,36 \\
\hline $\mathrm{r}_{\mathrm{y} 3.2}$ & 0,386 & $4,15^{* *}$ & 1,66 & 2,36 \\
\hline $\mathrm{r}_{\mathrm{y} 3.12}$ & 0,229 & $2,34^{*}$ & 1,66 & 2,36 \\
\hline
\end{tabular}

Keterangan :

* : koefisien korelasi parsial signifikan $\left(t_{h i t}=2,34>t_{t a b}=\right.$ 


\section{$1,66$ pada $a=0,05)$}

Interpretasi dari hasil analisis di atas adalah, jika variabel pengelolaan sekolah dan partisipasi masyarakat dalam meningkatkan mutu sekolah dikontrol, ternyata variabel iklim sekolah mempunyai hubungan positif dengan efektivitas sekolah.

Hipotesis keempat penelitian ini adalah terdapat hubungan positif antara pengelolaan sekolah, iklim sekolah, dan partisipasi masyarakat dalam meningkatkan mutu sekolah secara bersama-sama dengan efektivitas sekolah. pengujian hipotesis keempat dengan menggunakan rumus korelasi Pearson Product Moment. Dari hasil perhitungan, diperoleh koefisien korelasi antara pengelolaan sekolah, iklim sekolah, dan partisipasi masyarakat dalam meningkatkan mutu sekolah secara bersama-sama dengan efektivitas sekolah, $R_{y \cdot 123}=0,79$. Uji keberartian korelasi jamak dilakukan dengan uji F. Hasil perhitungan uji keberartian korelasi jamak tertera pada tabel 9

\section{Tabel 9}

Hasil Pengujian Keberartian Koefisien Korelasi Jamak

\begin{tabular}{|c|c|c|c|c|}
\hline $\mathrm{n}$ & $\mathrm{R}_{\mathrm{y} .123}$ & $\mathrm{~F}_{\text {hit }}$ & $\mathrm{F}_{\mathrm{tab}} \mathrm{\alpha}=0,05$ & $\mathrm{~F}_{\mathrm{tab}} \mathrm{\alpha}=0,01$ \\
\hline 100 & 0,79 & $54,49^{* *}$ & 3,91 & 6,90 \\
\hline
\end{tabular}

Keterangan :

$R_{\mathrm{y} .123}$ : koefisien antara $X_{1}, X_{2}$ dan $X_{3}$ secara bersama-sama dengan $Y$

** : koefisien korelasi jamak sangat signifikan $\left(\mathrm{F}_{\text {hit }}=54,49>\mathrm{F}_{\mathrm{tab}}=6,90\right.$ pada $\mathrm{a}=$ $0,01)$

Berdasarkan hasil pengujian tersebut dapat disimpulkan bahwa hubungan antara pengelolaan sekolah, iklim sekolah, dan partisipasi masyarakat dalam meningkatkan mutu sekolah secara bersama-sama dengan efektivitas sekolah adalah positif. Berdasarkan angka koefisien korelasi tersebut dapat dihitung pula koefisien determinasinya $\left(\mathrm{R}_{\mathrm{y} .123}\right)^{2}$ sebesar $0,792=63 \%$. Hal ini berarti bahwa $63 \%$ dari efektivitas sekolah dapat dijelaskan secara bersama-sama oleh ketiga variabel bebas dalam penelitian ini, yaitu pengelolaan sekolah, iklim sekolah, dan partisipasi masyarakat dalam meningkatkan mutu sekolah.

Peringkat hubungan antara setiap variabel bebas dengan variabel terikat dalam penelitian ini didasarkan atas perhitungan koefisien korelasi parsial. Ringkasan hasil perhitungan tersebut disajikan pada tabel 10 di bawah ini:

Tabel 10

Ringkasan Hasil Perhitungan Koefisien Korelasi Parsial

\begin{tabular}{|c|c|c|}
\hline Koefisien Korelasi parsial & $\mathrm{r}_{\text {hit }}$ & Peringkat \\
\hline $\mathrm{r}_{\mathrm{y} 1.23}$ & 0,325 & Pertama \\
\hline $\mathrm{r}_{\mathrm{y} 2.13}$ & 0,296 & Kedua \\
\hline $\mathrm{r}_{\mathrm{y} 3.12}$ & 0,229 & ketiga \\
\hline
\end{tabular}

Tabel di atas menunjukkan bahwa variabel bebas yang paling kuat hubungannya secara parsial dengan variabel terikat adalah pengelolaan sekolah sebagai peringkat pertama, diikuti oleh iklim sekolah dan partisipasi masyarakat dalam meningkatkan mutu sekolah, masing-masing sebagai peringkat kedua dan ketiga. 


\section{PENUTUP}

Kesimpulan. Berdasarkan hasil analisis data yang dikemukakan dapat disimpulkan sebagai berikut: Pertama: Terdapat hubungan positif antara variabel pengelolaan sekolah dengan efektivitas sekolah. Hal ini berarti bahwa efektivitas sekolah dapat ditingkatkan dengan pengelolaan sekolah. Pengelolaan sekolah di suatu sekolah memiliki pengaruh yang amat signifikan untuk meningkatkan efektivitas sekolah. Dengan kata lain semakin tinggi pengelolaan sekolah di suatu sekolah maka akan semakin tinggi pula efektivitas sekolah. Kedua: Terdapat hubungan positif dan sangat signifikan antara iklim sekolah dengan efektivitas sekolah. Hal ini berarti bahwa efektivitas sekolah dapat ditingkatkan dengan iklim sekolah. Iklim sekolah memiliki pengaruh yang signifikan pula terhadap peningkatan efektivitas sekolah. Semakin baik iklim sekolah maka akan semakin baik pula efektivitas sekolah. Ketiga: Terdapat hubungan positif dan sangat signifikan antara partisipasi masyarakat dalam meningkatkan mutu sekolah dengan efektivitas sekolah. Hal ini berarti bahwa efektivitas sekolah dapat dijelaskan oleh partisipasi masyarakat dalam meningkatkan mutu sekolah. Partisipasi masyarakat dalam meningkatkan mutu sekolah memiliki pengaruh yang signifikan pula terhadap efektivitas sekolah. Semakin tinggi partisipasi masyarakat dalam meningkatkan mutu sekolah maka akan semakin tinggi pula efektivitas sekolah. Keempat: Terdapat hubungan positif antara pengelolaan sekolah, iklim sekolah, dan partisipasi masyarakat dalam meningkatkan mutu sekolah secara bersama-sama dengan efektivitas sekolah. Hal ini berarti bahwa efektivitas sekolah dapat dijelaskan secara bersama-sama oleh ketiga variabel bebas dalam penelitian ini, yaitu pengelolaan sekolah, iklim sekolah, dan partisipasi masyarakat dalam meningkatkan mutu sekolah. Kesimpulan ini artinya bahwa efektivitas sekolah mempunyai keterkaitan dengan upaya meningkatkan pengelolaan sekolah, iklim sekolah yang kondusif dan partisipasi masyarakat dalam meningkatkan mutu sekolah.

Saran. Beberapa saran yang diberikan, yaitu: 1) Sekolah perlu meningkatkan pelaksanan manjemen sekolah yang transparan, akuntabel, efektif, dan partisipatif dengan menumbuhkan sikap disiplin terhadap para guru, pegawai, dan siswa di sekolah. 2) Kepala sekolah melakukan pengambilan keputusan yang tepat dengan menciptakan iklim sekolah yang dinamis, kondusif, menyenangkan dan mengasikkan sesuai dengan legitimasi yang dimiliki.3) Sekolah melakukan komunikasi yang efektif kepada seluruh warga sekolah, untuk mendelegasikan dan mengarahkan seluruh guru, pegawai, dan peserta didik dalam melakukan tugas masing-masing di sekolah. 4) Sekolah perlu menjalin hubungan yang harmonis berdasarkan aspirasi dan kebutuhan yang diharapkan masyarakatnya. 5) Dinas Pendidikan, masyarakat, dan instansi terkait dalam penyelenggaraan pendidikan perlu lebih memperhatikan dan membantu upaya peningkatan mutu sekolah.

\section{DAFTAR RUJUKAN}


Birmingham, John West. Managing Quality in Schools: Effective Strategies for Quality-Based School Improvement. London: Prentice Hall, 1997.

Darling, Hammond. The Right to Learner. San Francisco: Jossey - Bass Publishers, 1997.

Newell, Clarence A. Human Behavior in Educational Administration. London: Prentice-Hall International, 1978.

Owens, Robert G. Organizational Behaviour in Education. Instructional Leadership and School Reform, 1987.

Paine, et al. Total Quality in Education. London: Ashton Scholastic, 1992.

Schmoker, Mike. School and District Improvement. Assesment, Curriculum and Staff Development. Education Leadership, 2006.

Taylor, Frederic. Principles of Scientific Management.

http://choo.fis.utoronto.ca/FIS/courses/LIS1230/LIS1230Osharma/motive7.html 